\title{
ACROMIAL MORPHOLOGY AND SUBACROMIAL IMPINGEMENT SYNDROME: A CLINICO-ANATOMICAL STUDY
}

\author{
Susmita Saha ${ }^{1}$, Neelam Vasudeva², Prachi Saffar Aneja ${ }^{3}$, Amit Saxena $^{4}$
}

${ }^{1}$ Assistant Professor, Department of Anatomy, Faculty of Medical \& Health Sciences, SGT University, Budhera, Gurgaon.

${ }^{2}$ Director, Professor and HOD, Department of Anatomy, Maulana Azad Medical College, New Delhi.

${ }^{3}$ Associate Professor, Department of Anatomy, Faculty of Medical \& Health Sciences, SGT University, Budhera, Gurgaon.

${ }^{4}$ Associate Professor, Department of Anatomy, Faculty of Medical \& Health Sciences, SGT University, Budhera, Gurgaon.

ABSTRACT
BACKGROUND
The purpose of this present study was to observe the morphological variations of adult acromion processes by subjective
evaluation method, because morphologic variants of adult acromion processes play an important role in the pathogenesis of various
disorders of the shoulder joint and rotator cuff - particularly Subacromial Impingement Syndrome (SAIS).

\section{MATERIALS AND METHODS}

Two hundred adult dry scapulae from the osteology museum of MAMC, New Delhi, were obtained for evaluation of morphologic pattern of acromion process by visual inspection according to Bigliani's classification. We have also done subjective evaluation (visual inspection) on 32 supraspinatus outlet radiographs from patients suffering from subacromial impingement syndrome (as per inclusion criteria) for morphological variant of acromion process according to Bigliani's classification. Our observations were compared with other osteological and radiographic studies performed on different other population groups.

\section{RESULTS}

Of the 200 scapulae studied, 91 belonged to right side and 109 belonged to left side. By visual inspection, 35\% scapulae displayed type I (flat) acromion; 61\% scapulae exhibited type II (curved) acromion; only 4\% scapulae displayed type III (hooked) acromi on process. Frequency distribution of acromial shape on supraspinatus outlet view of SAIS patients shows 46.87\% type II (curved) acromion process; $53.12 \%$ exhibited type III (hooked) acromion process. No Type I (flat) acromion process was observed in radiographs of SAIS cases.

\section{CONCLUSIONS}

Predominantly type II (curved) acromion processes were observed in general population by visual inspection. But, among the cases it was mainly type III (hooked) type of acromion process. So the clinicians should be well versed with the appearance of acromion on dry bones, so that they can interpret acromial morphology on radiographs and MRI scans. Association between SAIS and acromial variant is well documented. So results of this subjective evaluation may be of help not only to the anthropologists, anatomists, but also for the orthopaedic surgeons.

\section{KEYWORDS}

Acromion Process; Morphology; Subjective Evaluation; Subacromial Impingement Syndrome; Supraspinatus Outlet View.

HOW TO CITE THIS ARTICLE: Saha S, Vasudeva N, Aneja PS, et al. Acromial morphology and subacromial impingement syndrome: a clinico-anatomical study. J. Evolution Med. Dent. Sci. 2016;5(76):5645-5649, DOI: 10.14260/jemds/2016/1273

\section{INTRODUCTION}

Subacromial Impingement Syndrome (SAIS) is one of the most common disorders of the shoulder resulting in functional loss and disability with symptoms like pain, weakness and loss of motion. ${ }^{1}$ SAIS is believed to be caused by compression of the rotator cuff tendons and subacromial bursa between the humeral head and structures that make up the coracoacromial arch. ${ }^{2}$ So reasons for impingement includes A-C joint arthritis, calcified CAL, structural abnormalities of the acromion and weakness of the rotator cuff muscles. ${ }^{2}$

Financial or Other, Competing Interest: None.

Submission 16-08-2016, Peer Review 09-09-2016,

Acceptance 15-09-2016, Published 22-09-2016.

Corresponding Author:

Dr. Susmita Saha

Flat No. 8 C,

PKT 10B Blk- 7, Iasola,

New Delhi-110025.

E-mail: drsusmita.sh@gmail.com

DOI: $10.14260 /$ jemds $/ 2016 / 1273$ and coracoid process are very important in the determination of height of subacromial space; any variations of these three structures can predispose to the beginning of the impingement syndrome. ${ }^{3}$

Hamilton, in 1875, identified acromial morphology as a potential source of symptoms in the shoulder and noted that an acromion process could limit motion because of its slight downward displacement. 4 In 1986, Bigliani et al identified three types of acromial morphology on dry scapulae by visual inspection as type I (flat); type II (curved) 55; type III (hooked). ${ }^{5}$ Since then, Bigliani et al classification was the most popular classification for the morphology of the acromion processes. In 1996, Getz et al evaluated acromial shape by objective method and reported $22.8 \%$ type I; $68.5 \%$ type II and $8.6 \%$ type III acromion processes. ${ }^{6}$ Many other authors Yazici et al, ${ }^{7}$ Shah et al, ${ }^{8}$ Nigar et al, ${ }^{9}$ Natsis et al, ${ }^{10}$ Paraskevas et al, ${ }^{11}$ Collipal et al,12 Jose et al ${ }^{13}$ and Naidoo et al ${ }^{14}$ also evaluated acromion processes among different other population group through dry scapulae. 
To the best of our knowledge, very few studies have been undertaken for the determination of acromial shapes among Indian population. In 1987, Morrison and Bigliani also evaluated 200 supraspinatus outlet radiographs of SAIS patients by visual inspection only and concluded that the rotator cuff tear was associated with type III acromion process. ${ }^{15}$ Many other authors like Toivenon et al,16 Nicholson et al,17 Wang et al,18 Shah et al, ${ }^{8}$ Nigar et al,9 Sangiampong et $\mathrm{al}^{19}$ and Mohamed et $\mathrm{al}^{20}$ also studied radiographs to determine different varieties of acromion processes by visual observation among SAIS cases. Though MRI scans are mainly preferred for soft tissue pathologies in the shoulder region, but also as a routine process supraspinatus outlet view may be recommended among SAIS cases. Considering the increasing numbers of such cases; it is expected that various morphological variations of adult acromion processes by subjective evaluation will serve as a reference base. Not only that, this data is also showing an association between SAIS and type II (curved) and II (hooked) acromion, which will help the radiologist and orthopaedicians to diagnose such cases as well as decide the modality of treatment.

\section{MATERIALS AND METHODS}

Subjective evaluation (Visual inspection) was done on 200 adult dry scapulae obtained from the osteology museum Department of Anatomy, MAMC, New Delhi. Morphologic parameters like sides of the scapulae and shape of the acromion process were noted. Acromial morphology was typed according to visual inspection by Bigliani's classification. Plain X-rays (Supraspinatus outlet radiographs) of 32 patients suffering from SAIS or rotator cuff tear (20 males and 12 females, 30-63 years age) were also evaluated to determine acromial morphology by visual inspection. To test the association, statistical analysis as chi square test was applied. ${ }^{21}$

\section{RESULTS}

Of the 200 scapulae studied, 91 belonged to right side and 109 belonged to left side. By visual inspection method of Bigliani et al, we have obtained the following results: 70 scapulae (out of that 38 of right side and 32 of left side) displayed type I (flat) acromion process; 122 scapulae (50 of right side and 72 of left side) showed type II (curved) acromion process and 8 scapulae (3 of right side and 5 of left side) exhibited type III (hooked) acromion process. This result has been shown in Table 1.

\begin{tabular}{|c|c|c|c|c|}
\hline $\begin{array}{c}\text { Acromial } \\
\text { Type }\end{array}$ & $\begin{array}{c}\text { Right } \\
\text { Side }\end{array}$ & $\begin{array}{c}\text { Left } \\
\text { Side }\end{array}$ & $\mathbf{n}$ & $\mathbf{\%}$ \\
\hline Type I & 38 & 32 & 70 & 35 \\
\hline Type II & 50 & 72 & 122 & 61 \\
\hline Type III & 3 & 5 & 8 & 4 \\
\hline Total & $\mathbf{9 1}$ & $\mathbf{1 0 9}$ & $\mathbf{2 0 0}$ & $\mathbf{1 0 0}$ \\
\hline \multicolumn{7}{|c|}{ Table 1: Frequency Distribution of Acromial } \\
Morphology in Relation to Sides of the Scapulae \\
\hline
\end{tabular}

To test the association, chi square test has been applied. $\mathrm{P}$ value is 0.1837 , that means $P>.05$; association is not significant.

X-ray evaluation of the 32 patients suffering from SAIS were done in supraspinatus outlet view to ascertain acromial morphology and it was seen that out of 32 patients, 15 patients had type II (curved) acromion process and 17 patients had type III (hooked) acromion process. The 200 dry scapulae were taken as control; when the acromial morphology of control (200 dry scapulae) and cases (32 patients with SAIS) was correlated, we found that in control group there were 70 scapulae of type I acromion; 122 scapulae were of type II and 8 scapulae of type III acromion. Among the cases, there were 15 type II and 17 type III, and no type I acromion was found. These observations are tabulated in Table 2.

\begin{tabular}{|c|c|c|c|c|}
\hline \multirow{2}{*}{$\begin{array}{c}\text { Acromial } \\
\text { Type }\end{array}$} & \multicolumn{2}{|c|}{$\begin{array}{c}\text { Control } \\
\text { (Dry Bones ) }\end{array}$} & \multicolumn{2}{c|}{ SAIS Cases } \\
\cline { 2 - 5 } & $\mathbf{n}$ & $\mathbf{\%}$ & $\mathbf{n}$ & $\mathbf{\%}$ \\
\hline Type I & 70 & 35 & 0 & 0 \\
\hline Type II & 122 & 61 & 15 & 46.87 \\
\hline Type III & 8 & 4 & 17 & 53.12 \\
\hline Total & 200 & & 32 & \\
\hline \multicolumn{3}{|c|}{ Table 2: Distribution of Acromial Morphology } \\
among Control \& Cases \\
\hline
\end{tabular}

To test the association, chi square test has been applied. The chi square value is 73.912 and its $\mathrm{P}$ value is $<2.2 \times 10^{-16}$, that means $\mathrm{P}<0.05$. Association is very much significant between the two groups.

The morphological pattern of acromion process in dry scapulae has been displayed in Fig. 1.
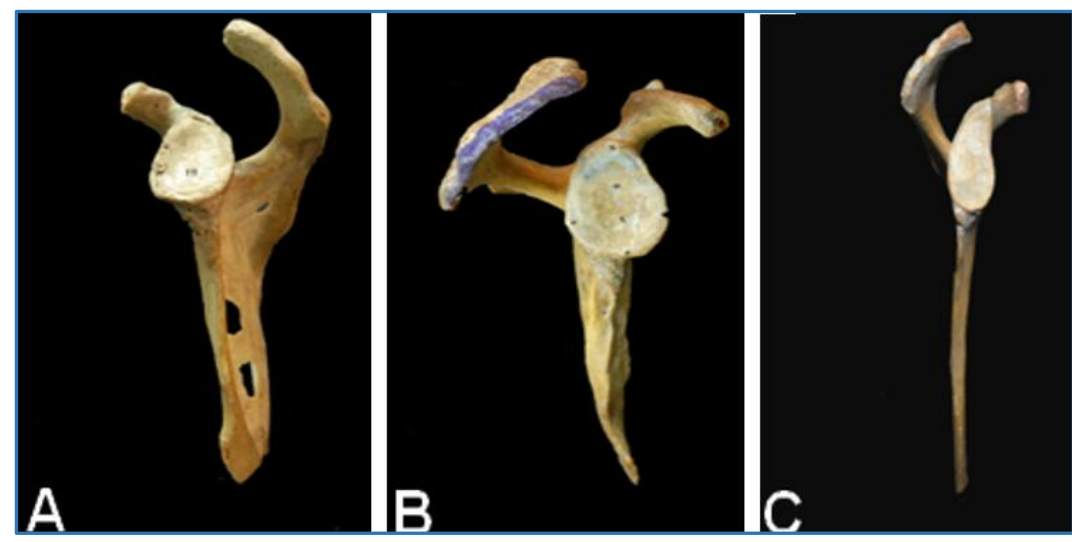

Fig. 1: A) Lateral View of Left Scapula Displaying Type I (Flat) Acromion;

B) Lateral View of Right Scapula Demonstrating Type II (Curved) Acromion; C) Lateral View of Right Scapula showing Type III (Hooked) Acromion 

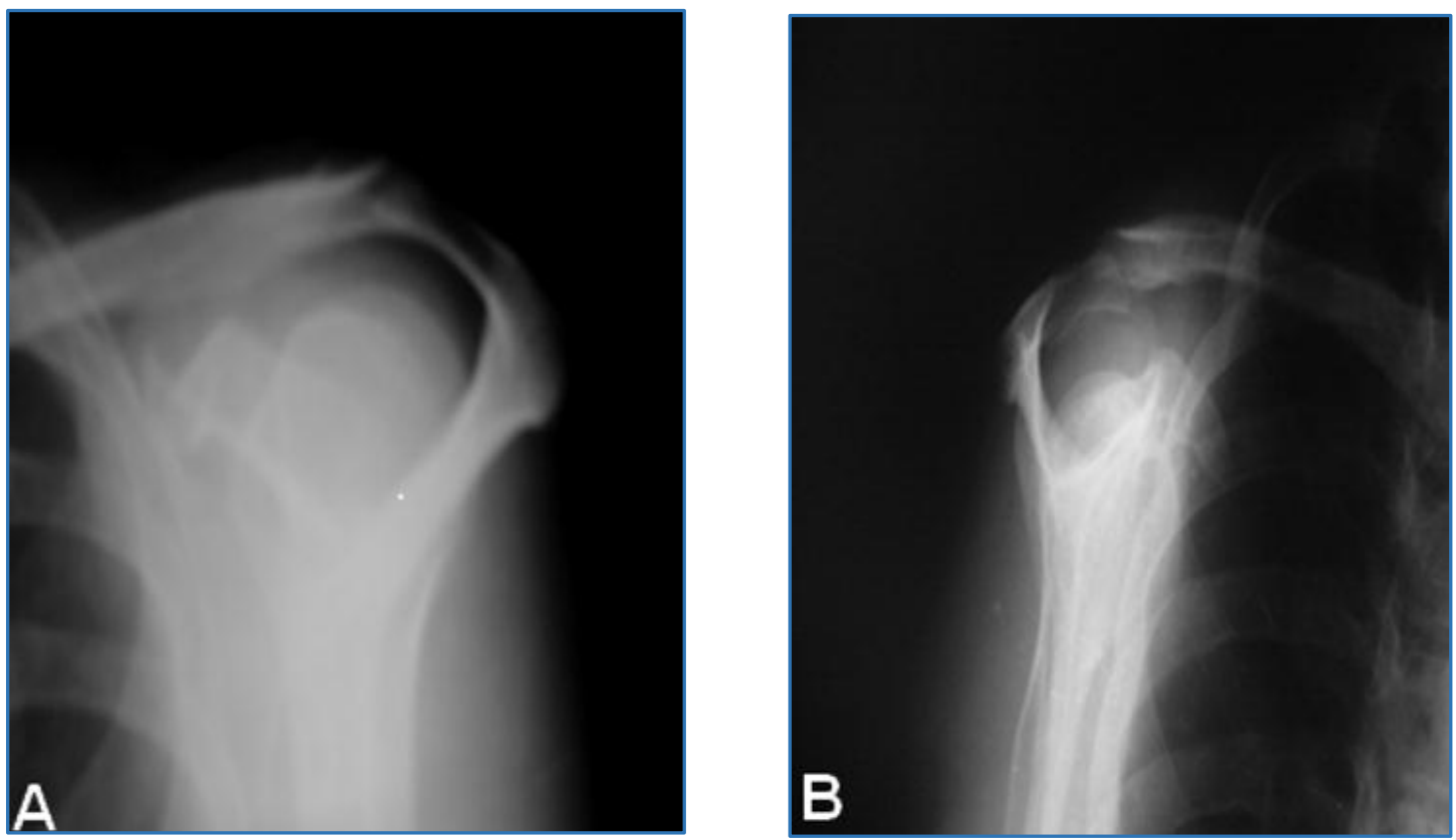

Fig. 2: Acromion Process among the Cases in the Supraspinatus Outlet View has also been Exhibited A) Left Supraspinatus Outlet View Displaying Type II (Curved) Acromion B) Right Supraspinatus Outlet View Exhibiting Type III (Hooked) Acromion Process

\section{DISCUSSION}

The acromion is believed to be an important osteological landmark constituting one of the three processes of the scapula.22 Prescher in 2001 identified the acromion as the summit of the shoulder at its attachment to the clavicle, which usually protrudes forward as it curves almost rectangularly from the acromial angle at the lateral aspect of the spine of the scapula. ${ }^{23}$ The acromion, coracoacromial ligament and coracoid process of the scapula, all together forms the coracoacromial arch which is the superior border (roof) of the subacromial space. ${ }^{24}$ Through this space, structures like rotator cuff tendons, long head of biceps tendon and the bursa all traverse.

Normally, bursa facilitates the motion of the rotator cuff beneath the arch. Abnormalities that disturb the relationship of these subacromial structures may lead to impingement. 25 So impingement of rotator cuff tendon and overlying bursa between the anterior coracoacromial arch and humeral tuberosities is an important cause of shoulder pain as well as disability. ${ }^{2}$ The concept of shoulder Subacromial Impingement Syndrome (SAIS) was introduced by Neer in 1972 and represents mechanical compression of the rotator cuff, subacromial bursa and biceps tendon against the under surface of the acromion and CAL, especially during elevation of the arm.

Neer stated that as many as $95 \%$ of all rotator cuff tears could be attributed to mechanical impingement. ${ }^{26}$ Though there are many other causative factors for SAIS, but variations in the shape and slope of the anterior aspect of the acromion were responsible for SAIS and associated tears of rotator cuff. For this reason, different types of studies have been undertaken to determine the acromial shape in living and nonliving subjects like radiographic evaluation of shoulder among SAIS patients and subjective evaluation (visual inspection) among dry scapulae. Though Bigliani et $\mathrm{al}^{5}$ introduced the most popular classification of acromial morphology by visual inspection among dry bones as well as radiographs, since then most of the other authors have also followed subjective evaluation method for determining acromial morphology whether in dry bones or in the supraspinatus outlet radiographs in different population group with different sample sizes. The distribution of acromial morphology in other population group by visual inspection has been displayed in the Table 3.

\begin{tabular}{|c|c|c|c|c|c|}
\hline $\begin{array}{c}\text { Authors } \\
\text { (Year) }\end{array}$ & Population & $\begin{array}{c}\text { Type } \\
\text { I, \% }\end{array}$ & $\begin{array}{c}\text { Type } \\
\text { II, \% }\end{array}$ & $\begin{array}{c}\text { Type } \\
\text { III, } \\
\text { \% }\end{array}$ & $\begin{array}{c}\text { Type } \\
\text { IV, } \\
\text { \% }\end{array}$ \\
\hline $\begin{array}{c}\text { Bigliani } \\
\text { et al } \\
(1986)\end{array}$ & American & 18.6 & 42 & 38.6 & - \\
\hline $\begin{array}{c}\text { Yazici et al } \\
(1995)\end{array}$ & Turkish & 22.5 & 70 & 5 & 2.5 \\
\hline $\begin{array}{c}\text { Shah et al } \\
(2001)\end{array}$ & $\begin{array}{c}\text { United } \\
\text { kingdom }\end{array}$ & 17 & 83 & - & - \\
\hline $\begin{array}{c}\text { Nigar et al } \\
\text { (2006) }\end{array}$ & Turkish & 10 & 73 & 17 & - \\
\hline $\begin{array}{c}\text { Natsis et al } \\
\text { (2007) }\end{array}$ & Greece & 12.1 & 56.5 & 28.8 & 2.6 \\
\hline $\begin{array}{c}\text { Paraskeva } \\
\text { s et al } \\
\text { (2008) }\end{array}$ & Greece & 26.1 & 55.6 & 18.1 & - \\
\hline $\begin{array}{c}\text { Collipal } \\
\text { (2010) }\end{array}$ & Chile & 8 & 50 & 42 & \\
\hline $\begin{array}{c}\text { Singh J } \\
\text { (2013) }\end{array}$ & India & 22.5 & 38.8 & 38.8 & \\
\hline $\begin{array}{c}\text { Jose et al } \\
\text { (2014) }\end{array}$ & Brazilian & 43.3 & 47.7 & 9 & \\
\hline $\begin{array}{c}\text { Naidoo } \\
\text { et al } \\
(2015)\end{array}$ & South & 34.6 & 51.1 & 14 & \\
\hline $\begin{array}{c}\text { Present } \\
\text { Study } \\
(2016)\end{array}$ & India & 35 & 61 & 4 & - \\
\hline $\begin{array}{c}\text { Table 3: Distribution of Acromial Morphology among } \\
\text { Dry Bones in Different Population Group }\end{array}$ & \\
\hline
\end{tabular}


We have noticed that in the literature, the prevalence of acromial morphology varies to a great extent.

The results of our study are similar to Yazici et al, Shah et al, Paraskevas et al, Jose et al and Naidoo et al. All these authors have also observed a higher incidence of type II (curved) acromion followed by type I (flat) and a very low incidence of type III acromion (hooked) process. Yazici et al and Natsis et al have also reported about type IV type of acromion, but we did not identify such type of acromion. Our results are different from studies done by Bigliani et al, Natsis et al, Nigar et al, Collipal et al and Singh et al, because they observed a higher incidence of curved acromion followed by hooked acromion and a very low incidence of flat acromion process. Though the population group of Singh J et al and ours are same, in Indians, but still the result is different. This variable acromial morphology hold important clinical as well as anthropological values, so recently we have conducted this subjective evaluation of acromial morphology on a larger sample size among the Indian population. Apart from this, we have also evaluated supraspinatus outlet radiograph of SAIS cases to determine the acromial morphology and we have compared our results with other studies on different population groups; displayed in Table 4.

\begin{tabular}{|c|c|c|c|c|}
\hline $\begin{array}{c}\text { Authors } \\
\text { (Year) }\end{array}$ & $\begin{array}{c}\text { Type } \\
\text { I, \% }\end{array}$ & $\begin{array}{c}\text { Type } \\
\text { II, \% }\end{array}$ & $\begin{array}{c}\text { Type } \\
\text { III, \% }\end{array}$ & $\begin{array}{c}\text { Type } \\
\text { IV, } \\
\text { \% }\end{array}$ \\
\hline $\begin{array}{c}\text { Bigliani et al } \\
\text { (1986) }\end{array}$ & 18.6 & 42 & 38.6 & - \\
\hline $\begin{array}{c}\text { Morrison } \\
\text { et al (1987) }\end{array}$ & 18 & 41 & 41 & - \\
\hline $\begin{array}{c}\text { Toivenon } \\
\text { et al (1995) }\end{array}$ & 5.4 & 62.5 & 32.1 & - \\
\hline $\begin{array}{c}\text { Nicholson } \\
\text { et al (1996) }\end{array}$ & 32 & 42 & 26 & - \\
\hline Wang et al (2000) & 6 & 66 & 28 & - \\
\hline Shah et al (2001) & 17 & 83 & - & - \\
\hline Nigar et al (2006) & 10 & 73 & 17 & - \\
\hline $\begin{array}{c}\text { Sangiampong et al } \\
\text { (2007) }\end{array}$ & 3.2 & 93.5 & 3.2 & - \\
\hline $\begin{array}{c}\text { Mohamed RE } \\
\text { (2015) }\end{array}$ & 28.6 & 44.6 & 23.2 & 3.6 \\
\hline $\begin{array}{c}\text { Present Study } \\
\text { (2016) }\end{array}$ & - & 46.87 & 53.12 & - \\
\hline $\begin{array}{c}\text { Table 4: Distribution of the Acromial Morphology by } \\
\text { Radiographic Evaluation in the Literature }\end{array}$ \\
\hline
\end{tabular}

The results of our radiographic evaluation are similar to study done by Morrison et al, because in both cases higher incidence of type III (hooked) acromion process were observed followed by type II (curved) acromion. Our results differ from studies conducted by most of the other authors, because they reported a higher incidence of type II acromion as opposed to type III acromion. Not only that study done by Nicholson et al and Mohamed et al in American and Egyptian population respectively, observed a higher incidence of type II acromion followed by type I acromion process. But as in Indian population, we did not observe any type I acromion process among SAIS patients. So we can conclude that in general population type II (curved) acromion is mostly seen, but in the patients with impingement syndrome the incidence of type III and type II acromion process are much more as compared to type I.

\section{CONCLUSIONS}

Though many authors have studied acromial morphology by visual inspection in different population group with different sample sizes; but to the best of our knowledge, very few studies have been undertaken for the evaluation of acromial morphology in Indian population. As variable shape of acromion process bears a vital role in the pathogenesis of impingement syndrome, so keeping this fact in mind we have conducted this morphological evaluation of acromion process in dry bones as well as patients with impingement syndrome. Our study furnishes morphological data by subjective evaluation providing an anatomical baseline to correlate the radiologic findings with clinical presentations. This data will facilitate to the orthopaedic surgeon to devise appropriate operative strategy, so that the functionality of the shoulder joint can be restored.

\section{ACKNOWLEDGEMENT}

We wish to convey our sincere thanks to Dr. R. K. Suri, Director, Professor, Department of Anatomy, Vardhman Mahavir Medical College and Dr. Rohini Pakhiddey; Assistant Professor, Department of Anatomy, ESI Dental College and Hospital, Rohini, Delhi for their constant inspiration in writing the research article. We also wish to convey my thanks to Dr. Tanvir, Assistant Professor, Department of Preventive and Social Medicine, Faculty of Medicine and Health Sciences, SGT University for his immense help in the statistical analysis performed in our study. We also acknowledge the immense help received from the scholars whose articles are cited and included in the references of this manuscript.

\section{REFERENCES}

1. Michener LA, McClure PW, Karduna AR. Anatomical and biomechanical mechanisms of subacromial impingement syndrome. Clin Biomech (Bristol Avon) 2003;18(5):36979.

2. Fongemie AE, Buss DD, Rolnick SJ. Management of shoulder impingement syndrome and rotator cuff tears. American Family Physician 1998;57(4):667-74.

3. Torres AC, Riberio ASC, Maux DADSX, et al. Morphometry of acromion process and its clinical importance. Int J Morphol 2007;25(1):51-4.

4. Hamilton FH. Fracture of the scapulas. A practical treatise on fractures and dislocations. $5^{\text {th }}$ edn. Philadelphia: Henry C. Lea 1875:209-21.

5. Bigliani LU, Morrison DS, April EW. The morphology of acromion and rotator cuff impingement. Orthop Trans 1986;10:228.

6. Getz JD, Recht MP, Piraino DW, et al. Acromial morphology: relation to sex, age, symmetry and subacromial enthesophytes. Radiology 1996;199(3): 737-42.

7. Yazici M, Kopuz C, Gulman B. Morphologic variants of acromion in neonatal cadavers. J of Pediatric Orthopedics 1995;15(5):644-7.

8. Shah NN, Bayliss NC, Malcolm A. Shape of the acromion: congenital or acquired-a macroscopic study of acromion. J Shoulder Elbow Surg 2001;10(4):309-16.

9. Coskun N, Karaali K, Cevicol C, et al. Anatomical basics and variations of the scapula in Turkish adults. Saudi Med J 2006;27(9):1320-5. 
10. Natsis $\mathrm{K}$, Tsikaras $\mathrm{P}$, Totlis $\mathrm{T}$, et al. Correlation between the four types of acromion and the existence of enthesophytes: a study of 423 dried scapulas. Clinical Anatomy 2007;20(3):267-72.

11. Paraskevas G, Tzaveas A, Papaziogas B, et al. Morphological parameters of the acromion. Folia Morphol (Warsz) 2008;67(4):255-60.

12. Collipal E, Silva H, Ortega L, et al. The acromion \& its different forms. Int J Morphol 2010;28(4):1189-92.

13. Aragao JA, Silva LP, Reis FP, et al. Analysis on the acromial curvature \& its relationships with the subacromial space \& types of acromion. Rev Bras Ortop 2014;49(6):636-41.

14. Naidoo N, Lazarus L, Osman SA, et al. Acromial morphology \& subacromial architecture in a South African population. Int J Morphol 2015;33(3):817-25.

15. Morrison DS, Bigliani LU. The clinical significance of variation in acromial morphology. Orthop Trans 1987;11:234.

16. Toivenen DA, Tuite MJ, Orwin JF. Acromial structure and tears of the rotator cuff. J Shoulder Elbow Surg 1995;4(5):376-83.

17. Nicholson GP, Goodman DA, Flatow EL, et al. The acromion: morphologic condition and age related changes. A study of 420 scapulas. J Shoulder Elbow Surg 1996;5(1):1-11.

18. Wang JC, Shapiro MS. Changes in acromial morphology with age. J Shoulder Elbow Surg 1997;6(1):55-9.
19. Sangiampong A, Chompoongpong S, Sangvichien S, et al. Acromial morphology of Thais in relation to gender and age: study in scapular dried bone. J Med Assoc Thai 2007;90(3):502-7.

20. Mohamed RE, Abu-Sheisha DM. Assessment of acromial morphology in association with rotator cuff tear using MRI. Egyptian Journal Of Radiology \& Nuclear Medicine 2014;45(1):169-80.

21. R Core Team. A language \& environment for statistical computing. Foundation for statistical computing, Vienna, Austria. 2005. URL http://www.R-project.Org.

22. Standring S. Gray's anatomy: the anatomical basis of clinical practice. 40 th edn. Edinburg: Elsevier 2008.

23. Prescher A. Anatomical basics, variations \& degenerative changes of the shoulder joint \& shoulder girdle. Eur J Radiol 2000;35(2):88-102.

24. Flatow EL, Soslowsky LJ, Ticker JB, et al. Excursion of the rotator cuff under the acromion. Pattern of subacromial contact. Am J Sports Med 1994;22(6):779-88.

25. Bigliani LU, Norris TR, Fischer J. The relationship between the unfused acromial epiphysis and SAIS. Orthop Trans 1983; 7:138.

26. Neer CS. Anterior acromioplasty for the chronic impingement syndrome of the shoulder. J Bone Joint Surg Am 1972;54(1):41-50. 